\title{
The Wind in Reeds: A Storm, A Play, and The City That Would Not Be Broken
}

\author{
Edited by: Wendell Pierce
}

Reviewed by: Madison Jones, Intern, To Write Love on Her Arms

The Wind in the Reeds by Wendell Pierce is a memoir intertwined with rich personal accounts of New Orleans pre- and post-Katrina and the life-changing power of art, especially in relation to community. The title, explained by Pierce, brings together the essence of the book:

"The reeds sing a song of triumph. The harder the wind blows, the stronger our spirit, the purer our art, and the greater our victory" (p. 12).

Triumph, strength, and victory despite trials are central to The Wind. The book can be most useful for orientation leaders, staff, and students because of the way in which Pierce encourages empathy, action, and social justice.

During the first three chapters, Pierce delves into his family history. "Here are some of the stories that made me," he says, inviting us into the details of his family tree (p. 13). He reaches back several generations to his ancestors who were enslaved in the South who faced enormous hardship and abuse. These stories from the past, according to Pierce, inform his identity and experience even today. "My personal triumphs are not mine alone," writes Pierce, "they represent the victory of all my forebears" (p. 15). Roots run deep in his family, and the success he has achieved, he attributes to the suffering and turmoil that his family has faced over the years. He believes firmly in generational responsibility and the role that storytelling plays: "If we forget out stories, we will forget who we are, and 
we will forget who we must be to one another" (p. 15). Throughout the stories Pierce tells about his family, he forces the reader to think about the ways in which we carry our past, and to what extent our lineage affects our identities.

Like history, religion also impacts Pierce's life in great ways. Despite having faced racism within many Catholic churches, Pierce and most of his family still identify as Catholic. He speaks pretty candidly about his relationship with religion: "It's not that I don't believe in God. It's just that I struggle with doctrine. I connected with God through the love of my parents, whose belief was so unshakable" (p. 333). The death of his mother brings him to confront his spirituality because she was a devout churchgoer. Her relationship with the Catholic church was, though stronger than Pierce's, not without its pushbacks. "She stressed," according to Pierce, "that we have to separate the man-made from the divine, and that man is fallible" (p. 114). Regarding the man-made part of the Catholic church, Pierce explains, "The racial resentment of white New Orleans Catholics-including many priests-was so overwhelming that it defined them even more strongly than loyalty to church authority and Catholic teaching" (p. 114).

In 2005, hurricane Katrina devasted hundreds of homes and families in southern Louisiana. Pierce's immediate family was victim to the unrelenting storm, along with many of his family friends. According to Pierce, “For people who didn't live through it, no words can fully express the pain, the rage, the grief, and the futility we New Orleanians felt" (p. $3)$. The specific pain and loss that people-specifically lower-class Black communities-endured at this time in history was overwhelming and had lasting effects on the way people navigated everyday life. Katrina led Pierce back home. Arguably, Katrina is what led him to write this memoir. The storm's devastating effects that he witnessed firsthand opened his mind to the impacts of environmental racism. Black communities, he noticed, were being disproportionately impacted by the storms. Because of his success as an actor in Los Angeles, Pierce had the resources to help his family relocate and, eventually, rebuild. 
The power of art is a main theme that ties everything together in The Wind-the performance of Waiting for Godot being the experience that frames the book. Art created opportunities in Pierce's life. He attended New Orleans Center for Creative Arts (NOCCA) for three years in high school, where his love for acting flourished. He worked hard, and eventually had the opportunity to go to New York and attend Julliard, where he explored his identity through art, jazz, and the way he related to people in the North. Art was his life, and so much more: "Art tells us who we are, and it tells us who we must become. Art...empowers us to live life's questions...Art is the most serious thing we can do" (p. 11). Pierce firmly believes that art is a means to understand, explore, and navigate disasters. After Katrina, a close director friend of Pierce's drove through the devastated streets and thought Waiting for Godot could connect with those who were affected by the disaster. Pierce, too, was moved by the power of this play to connect with Katrina victims: "This production of Godot, in that weary time in that storm-battered place, helped me...And I was far from the only one" (p. 11).

Areas for critique in The Wind are concerned with issues that are in great contention today. Pierce sympathizes with police officers, despite his personal experiences with police violence. His perspective is that he "would not impugn all officers because of the conduct of a few" ( $p$. 192). This idea is controversial. Pierce is at risk for being interpreted as undermining the racism that police officers have perpetuated throughout the years, the lives they've taken, and the families who haven't received justice. He also was an actor in The Wire, a television show that has been under criticism for its portrayal of criminals as predominantly Black men, perpetuating the stereotype that Black men are all violent criminals. This is something for readers to keep in mind and potentially have dialogue about.

Pierce's unrelenting patriotism throughout the book is undeniable. He is prideful of America and the American military in a way that pushes absurdity and ignorance-ignorance to the harm, abuse, and trauma that goes on in military programs. There is a fine line between sympathy for veterans who have faced great hardships by being forced to be in the 
military (for reasons such as poverty, family reasons, any reason that is not fully autonomous, etc.), and full-fledged support of war. Pierce dances along that line. To be fair, Pierce's father was drafted, and his brother chose to participate in the military, so this pride is likely close to his heart in a personal way. His logic and his father's logic was, "To be proud of our country for what she will be one day, not for what she is today" (p. 54). Even though he is patriotic, he does recognize racial segregation and disparity in the military, and he addresses the question that Black men during segregation had to face: Why "love the country that persecuted them like the enemy?" (p. 61). For readers who may be highly conservative and pro-war, this perspective will be supported by Pierce's pro-militarism. For those of us who lean toward a more liberal worldview, there might be pushback.

Lastly, there is a moment in the text where Pierce explains the cultural transition from his small hometown in Louisiana to the hustle of New York City. As much as I've tried, I truly cannot understand its constructive purpose. On page 138, he explains that calling people of all genders "baby" in New Orleans was commonplace, a term of endearment. Naturally, he carried this lingo with him to Julliard. Problematically, he explains, "I didn't realize it, but in that first semester, I developed a reputation for being a ravenous bisexual- 'The Hound of the Hallway' as one woman called me" (p. 138). Further, his reaction to being rejected by a man who thought Pierce was hitting on him illustrated the mild and implicit homophobia that Pierce holds in this passage: "My jaw dropped. I had no idea that's how my commonplace Crescent City charm was being received. I dropped the 'baby' talk and I learned how to be harder and more closed" (p. 138). By including this section, Pierce implies that to be perceived as "a ravenous bisexual" was something appalling and just unheard of. This passage stands out as one of the more problematic areas of the memoir.

I imagine that this can be useful as a common reader for students because it broadly touches on universal aspects of the human condition while simultaneously speaking from a very specific personal experience. Despite the areas where I would criticize his arguments or points of view, Pierce's overall message is full of resilience and hope. 